\title{
The Formation and Structure Evolution of Zechstein (Upper Permian) Salt in Northeast German Basin: A Review
}

\author{
Yanqiu Zhang, Michael Krause, Maria Mutti \\ Institute of Earth and Environmental Science, University of Potsdam, Potsdam, Germany \\ Email: zhyq1998@126.com
}

Received October 21, 2013; revised November 16, 2013; accepted November 24, 2013

Copyright (C) 2013 Yanqiu Zhang et al. This is an open access article distributed under the Creative Commons Attribution License, which permits unrestricted use, distribution, and reproduction in any medium, provided the original work is properly cited.

\begin{abstract}
The Zechstein (Upper Permian) salts are extensively distributed in the Northeast German Basin (NEGB). Their formation and movements have attracted great attention to discovering the accumulation and exploration of hydrocarbon sources, as well as the salt production. But the previous studies are validated in cases and a general view on these studies is scarce. By analyzing and integrating previous studies, the history and structure evolution of Zechstein salts were reviewed in this paper. Seven cycles of Zechstein salt (Na1, Na2, Na3, Na4, Na5, Na6, Na7) with distinct composition and thickness were deposited after a series of marine transgressions and regressions during the Upper Permian. The Na1 $(300 \mathrm{~m}$ ) locally developed in a lagoon environment. The thick Na2 (over $500 \mathrm{~m}$ ) was widely deposited in the whole basin. The $\mathrm{Na} 3, \mathrm{Na} 4, \mathrm{Na} 5, \mathrm{Na} 6$ and $\mathrm{Na} 7$ decreased progressively in thickness and distribution. These salts should have been moved as a result of regional tectonics taking place from Triassic to Early Cenozoic, which changes the original distribution of salts, resulting in the formation of different salt structures (pillows and diapirs). Salt movement was more intensive in central and southern parts of the basin forming narrow and widely-distributed salt diapirs, while it was less intensive in the northern parts where salt pillows are the major structure. The salt meadow and saline springs are also present, which are attributed to the salinization of the groundwater. By this study, we review the history and structure development of the Zechstein salt in the NEGB by associating each individual study and figure out the common and regional characters of the salt in this region.
\end{abstract}

Keywords: Zechstein Salt; Salt Formation; Salt Movement; Salt Structure; Salt Dissolution

\section{Introduction}

Salts in the underground have been considered as a chemical base for production of many important industrial products. In addition, the thick salt is regarded as a suitable media for the disposal of nuclear waste due to their geologic stability, predictable engineering and physical behaviour and imperviousness to groundwater [1]. Salts also play an important role in the accumulation and exploration of hydrocarbon sources [2-7]. The Zechstein (Upper Permian) salt is the most widespread salt in the Northeast German Basin (NEGB) [8,9]. It contains rock salt, potassium-magnesium salts and thick sulphates in the structure of diapirs, pillows and walls $[10,11]$. It was reported that the Zechstein salt originated from the seawater. With the marine transgression, a flooding on cyclic Zechstein sedimentation is initiated in the Southern
Permian Basin [6,12-20]. After marine transgression, a regression is followed, which results in the lowering of sea level and the precipitation of the Zechstein salt at the arid climate. When the next marine transgression comes, the precipitation of Zechstein salt is ceased and the first cycle of the Zechstein salt forms. Followed by next marine transgression and regression, the subsequent cycles of the Zechstein salt are formed. In the NEGB, the thick Zechstein salt units (totally up to $2000 \mathrm{~m}$ in the basin center) are mainly formed in the Upper Permian.

The salts movement in the NEGB has been intensively studied because the structural setting of Mesozoic and Cenozoic deposits is strongly dependent on the distribution of mobilized Zechstein salt. Previous studies have discovered the salt moving path and the trigger force for such a process [8,10,21-30]. In 1960, the halokinetic model of basinal salt movement was first described by 
Trusheim [31] in the North German Basin. Since then, many mechanisms of salt movement have been proposed, but some of them are inconsistent. For example, Trusheim [31] suggested that the buoyancy is the major trigger to initiate the movement while other scientists $[8,23,28-30$, $32-34]$ proposed that the regional tectonics plays an important role in triggering the salt (Zechstein) movement. In addition, Waltham [35] suggested that the flexural buckling and hanging-wall drag of the overburden could cause salt movement much more than that caused by buoyancy. The controversy is also present in the study of salt deformation [35-43]. Vendeville and Jackson [44] suggested that regional extension can initiate and drive salt diapirism provoking thin-skinned deformation of the basin while Stewart and Coward [42] attributed the deformation to the compression of the sedimentary overburden.

The importance of salt and the existence of scientific controversy in the NEGB inspire us to make a review study on this sediment. Our aim is not only to overview the study of Zechstein salt in the NEGB but also to find the relevance of each individual study in this area. Our review starts from the formation of Zechstein salt followed by salt movement and its influence on the geological structures. A perspective on the Zechstein salt is pointed out in the end.

\section{Geological Setting}

The Northeast German Basin (NEGB) is a sub-basin of the Southern Permian Basin which extends from eastern
England through the Netherland and North Germany to Poland $[9,19]$. The NEGB is located in the south to the Harz Mountains, the north to the island Ruegen and east to the boundary of Poland (Figure 1). The NEGB presents asymmetric in geometry with different structural styles in the northern and the southern flanks, probably due to different basement structures [45]. The northern is steeper than southern showing different geometries [28]. Compared to the northern part of the basin, the southern margin is controlled by a large fault system (such as Gardelegen Fault, Figure 1).

The Sediments in the NEGB range in age from Permian to present and have a thickness of $10-12 \mathrm{~km}$ in the central parts $[11,46]$. The formation of the NEGB started in the Permo-Carboniferous with extensive volcanism $[19,46,47]$ (Figure 2). Following the cessation of volcanism the basin underwent the first and the maximum thermal subsidence which was lasted more than $250 \mathrm{Ma}$ (from Early Permian to the end of the Middle Triassic) $[9,11,29,48]$ resulting in the formation of Lower Permian (Rotliegend) composed of clastic sediments of Aeolian sandstones, fluvial fans and shallow-lake deposits [49] (Figure 2). The overlying Zechstein sequences are composed of cyclic carbonates and evaporites (salt and anhydrite), which were deposited as a result of repeated marine transgression in Upper Permian [16]. The Zechstein salt is up to $2 \mathrm{~km}$ thick in the center of basin. In the Mesozoic, in combination of a series of subsidences, the sedimentation was mainly controlled by transgressions and regressions of the Tethys Ocean from the south of the basin [19]. The Lower Triassic is characterized by

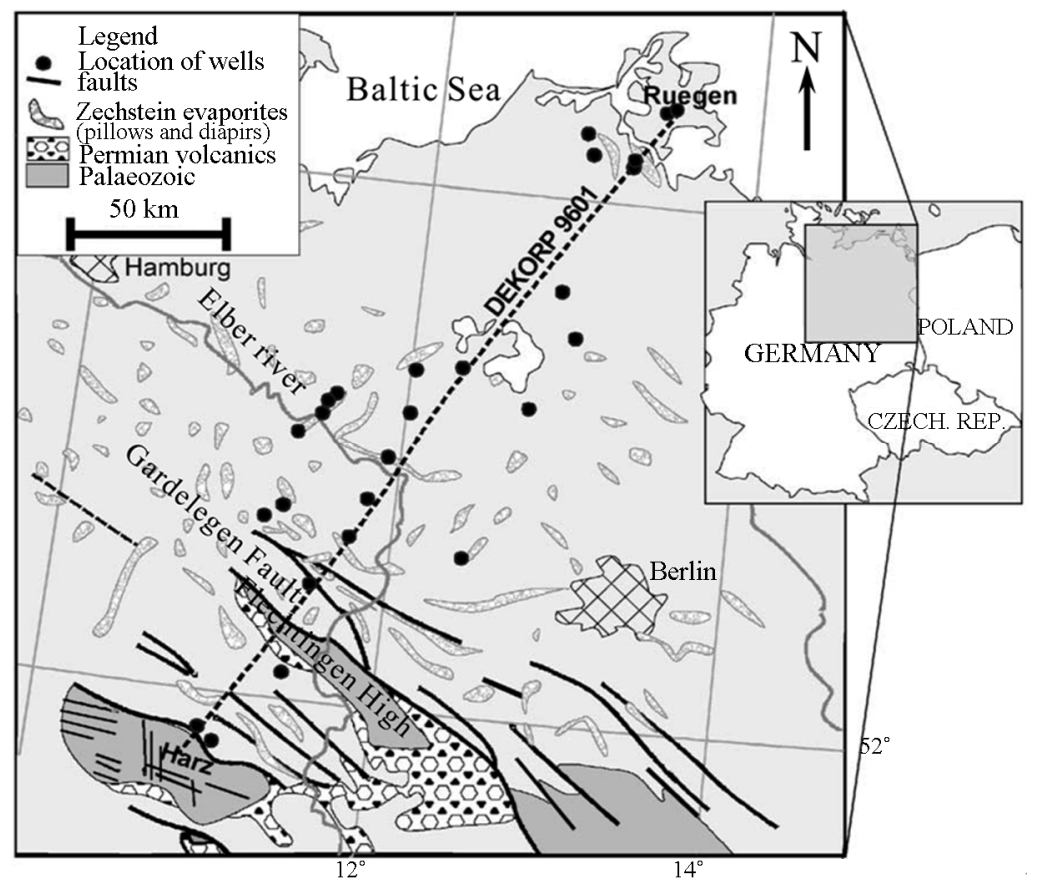

Figure 1. Location of the Northeast German Basin, based on [50]. 


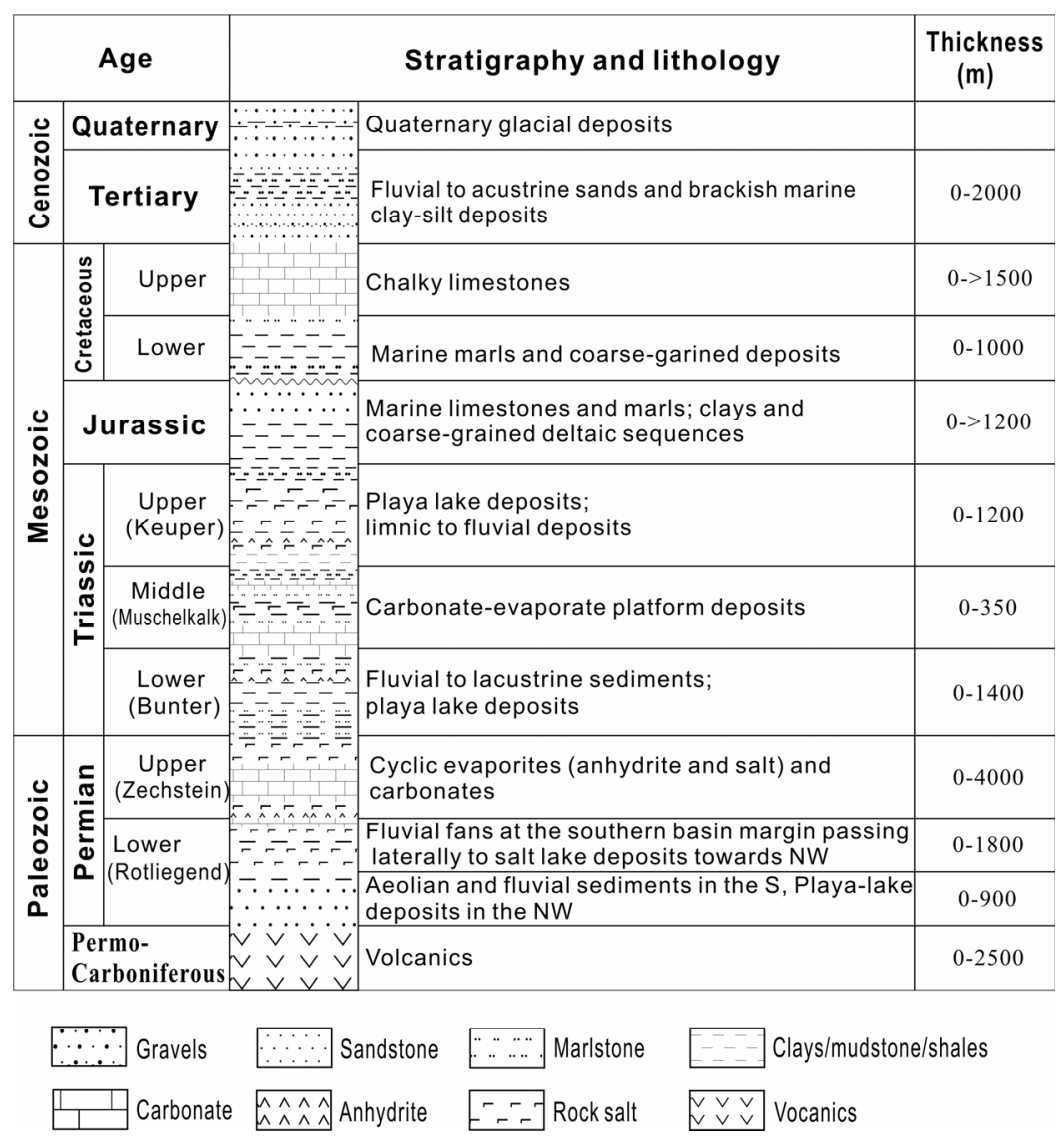

Figure 2. Stratigraphic sequences in the Northeast German Basin [11,51].

terrestrial red-bed sequences of clastic alluvial fans, lacustrine and sabkha deposits, overlain by Middle Triassic shallow marine carbonates [28]. In the Late Triassic, terrestrial facies were deposited with the interbedded by sequences of carbonates, anhydrite and halite. In the Jurassic and Cretaceous, the shallow marine environment sediments (marls and carbonates) were mainly deposited. However, parts of the Jurassic and Triassic sediments were eroded in some uplifted areas, especially in the northern part of the basin in the Late Jurassic to Early Cretaceous. The Cenozoic sediments consist of unconsolidated Tertiary to Quaternary deposits, which discordantly overlay Mesozoic strata. Tertiary sediments compose of fluvial sands, marine marls and clays while fine clayey and coarse-clastic sediments are deposited in Quaternary [29,50].

The huge Zechstein salt in the NEGB plays an important role in the deformation of the overburden $[8,10$, $11,30,32]$. Deformation geometry may vary in response of the direction and magnitude of regional stress as well as of the mechanical properties of other sedimentary layers. From Late Triassic to Early Jurassic, a regional E-W directed extension influenced the evolution of the NEGB and initiated the first period of Zechstein salt movement $[8,11,32,48,51]$. During the Late Cretaceous to Early
Cenozoic, a regional NNE-SSW directed compression not only leads to uplift and erosion in this basin with differential inversions in the southern part and along its margins, but also causes intensive salt movements $[8,10$, 32]. Towards the south the deformation of salt overburden is increased in the NEGB. In contrast, the salt layer is almost undeformed in the northwestern part of the ba$\sin [10]$. The internal structure of the NEGB is strongly determined by the distribution of salt $[29,45]$.

\section{Formation of Zechstein Salt}

Based on the chemical analysis of fluid inclusion in marine halite $[54,55]$, the Zechstein (Upper Permian) sequence in the NEGB was suggested to deposit in a time period of about 7 million years (from 258 to $251 \mathrm{Ma}$ ). The formation of Zechstein sequence is a result of a series of marine transgressions and regressions [56]. With a fall of the Zechstein sea level, the salinity of the seawater greatly increases as a result of high evaporation rate, which finally makes the seawater reach oversaturated. Carbonates firstly precipitated from seawater, subsequently followed by sulfates (anhydrite/gypsum). When salinity of seawater reached 10 to 12 times (340\% $360 \%$ ) of the normal seawater $(35 \%)$, halite $(\mathrm{NaCl})$ starts to precipitate [57]. And finally potassium-magne- 
sium salts precipitate from supersaline water when the concentration of seawater approached more than 70 - 90 times of the normal seawater. Following another transgression, the basin is filled with seawater again. Sequentially, with the decrease of sea level, another cycle of deposition starts in a nearly similar sequence. The fluctuation of sea level leads to the formation of Zechstein with seven cycles, from bottom to top: Werra (Z1), Stassfurt (Z2), Leine (Z3), Aller (Z4), Ohre (Z5), Friesland (Z6) and Fulda (Z7) in the NEGB (Figure 3). Within each cycle, the mineral composition represents the progressing evaporitic condition. An ideal cycle starts with a transgressive non-evaporitic sediment (conglomerate, at the margin of the basin, sand-silt-mudstone-pelite), followed by carbonate, sulphate phase (anhydrite/gypsum), and ended by rock salt (halite), potash (K- or Mg-) salt. However, all these cycles were not equally deposited throughout the whole basin. Four main evaporatic cycles (Z1 - Z4) can be distinguished whereas the Z5, Z6 and $Z 7$ are only locally developed in the NEGB. The salts in Z1, Z2, Z3 and Z4 have been intensively studied while the salts in Z5 (Na5), Z6 (Na6) and Z7 (Na7) are limitedly investigated. Therefore, the studies on $Z 1$ salt (Na1), $\mathrm{Z} 2$ salt (Na2), Z3 salt (Na3) and Z4 salt (Na4) would be

\begin{tabular}{|c|c|c|c|c|c|}
\hline \multicolumn{4}{|c|}{ German Zechstein cycles } & \multicolumn{2}{|c|}{ Lithostratigraphy } \\
\hline \multirow{13}{*}{ 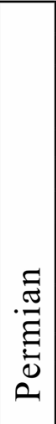 } & \multirow{6}{*}{\begin{tabular}{|l|}
251.2 \\
$(\mathrm{MA})$
\end{tabular}} & \multirow{3}{*}{ Fulda } & \multirow{3}{*}{$\mathrm{Z7}$} & $\mathrm{Na} 7$ & Fulda Salt \\
\hline & & & & A7 & Fulda Anhydrite \\
\hline & & & & T7 & Fulda Clay \\
\hline & & \multirow{3}{*}{ Friesland } & \multirow{3}{*}{ Z6 } & $\mathrm{Na6}$ & Friesland Salt \\
\hline & & & & A6 & Friesland Anhydrite \\
\hline & & & & T6 & Friesland Clay \\
\hline & \multirow[t]{6}{*}{$252-$} & \multirow{3}{*}{ Ohre } & \multirow{3}{*}{$\mathrm{Z5}$} & $\mathrm{Na5}$ & Ohre Salt \\
\hline & & & & A5 & Ohre Anhydrite \\
\hline & & & & T5 & Ohre Clay \\
\hline & & \multirow{3}{*}{ Aller } & \multirow{3}{*}{ Z4 } & $\mathrm{Na} 4$ & Aller Salt \\
\hline & & & & A4 & Pegmatite Anhydrite \\
\hline & & & & $\mathrm{T} 4$ & Red Salt Clay \\
\hline & \multirow{7}{*}{254.5} & \multirow{4}{*}{ Leine } & \multirow{4}{*}{$\mathrm{Z3}$} & $\mathrm{Na} 3$ & Leine Salt \\
\hline \multirow{11}{*}{$\underset{\sigma}{\stackrel{0}{\sigma}}$} & & & & A3 & Main Anhydrite \\
\hline & & & & $\mathrm{Ca} 3$ & Platy Dolomite \\
\hline & & & & T3 & Gray Salt Clay \\
\hline & & \multirow{3}{*}{ Stassfurt } & \multirow{3}{*}{$\mathrm{Z2}$} & $\mathrm{Na} 2$ & Stassfurt Salt \\
\hline & & & & $\mathrm{A} 2$ & Basal Anhydrite \\
\hline & & & & $\mathrm{Ca} 2$ & Stassfurt Carbonatc \\
\hline & \multirow{5}{*}{$256-$} & \multirow{5}{*}{ Werra } & \multirow{5}{*}{ Z1 } & \begin{tabular}{|l|l|} 
& A1ß \\
A1 & Nal \\
& A1 a \\
\end{tabular} & $\begin{array}{l}\text { Upper Anhydrite } \\
\text { Werra Salt } \\
\text { Lower Anhydrite }\end{array}$ \\
\hline & & & & $\mathrm{Ca} 1$ & Zechstein Limestone \\
\hline & & & & $\mathrm{T} 1$ & Copper Shale \\
\hline & & & & $\mathrm{T} 1 \mathrm{Ca}$ & ("Mutterfloz" Carbonate) \\
\hline & & & & $\mathrm{Z} 1 \mathrm{C}$ & Zechstein Conglomerate \\
\hline \multicolumn{4}{|c|}{ Early Permian } & \multicolumn{2}{|c|}{ Rotliegendes } \\
\hline
\end{tabular}

Figure 3. Lithostratigraphy of the Zechstein (Late Permian) in the NEGB. Zechstein cycles (Z1 - Z6) developed during 258 to 251 Ma, with Na1 (Zechstein salt) local occurrence and $\mathrm{Na} 2, \mathrm{Na} 3, \mathrm{Na} 4$ and $\mathrm{Na} 5$ extensive precipitation within this basin (modified from [16,54]). compared and analyzed as a majority of this paper.

\subsection{Zechstein 1 Salt (Na1)}

In the Early Upper Permian, following the initial transgression of Scandic Ocean (Greenland and Norwegian seas) the most Germany was flooded from northwest to south $[16,58,59]$. The transgression of Zechstein Sea was probably rapid and reached its maximum range at that time $[18,19,60,61]$. After the rapid transgression an extensive regression followed, which made the NEGB an increasing of salinity and $\mathrm{pH}$ as a result of high evaporation, leading to the precipitation of $\mathrm{Z} 1$ anhydrite (A1) and $\mathrm{Z} 1$ salt (Na1) (Figure 4). At the southern margin, a larger anhydrite platform developed with thickness up to $300 \mathrm{~m}$. Some barriers were built up by enormous A1 in the platform margin. Behind these barriers very thick salts (Na1) precipitated in the lagoon environment probably due to the higher evaporation rate in this area than that in open sea areas at the end of Z1 (Figure 5).

In the NEGB, Na1 is locally distributed, mainly in the east of the basin, which was isolated from areas to the west during the Z1 regression [59]. Two facies of Na1, the basin and lagoon facies can be identified in the NEGB. In the basin, the thickness of Nal is only $10 \mathrm{~m}$ to $60 \mathrm{~m}$ and its distribution is not uniform probably caused by the paleo-topography. In the lagoon, its thickness varies from $60 \mathrm{~m}$ to more than $300 \mathrm{~m}[59,62]$. From lagoon

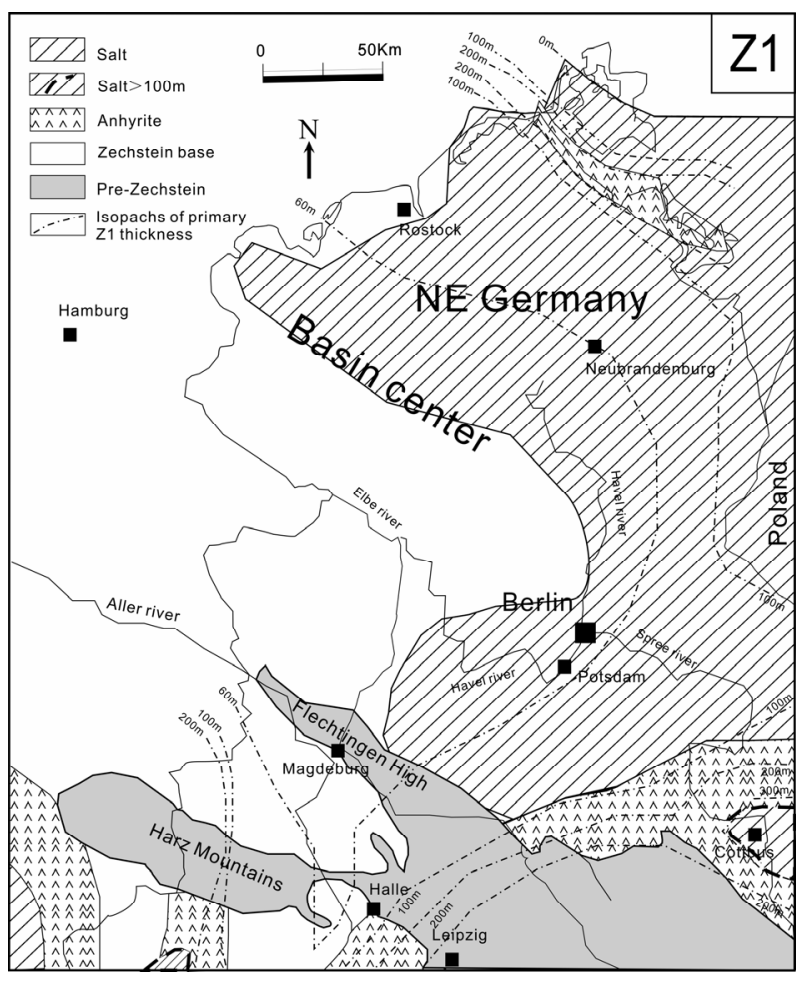

Figure 4. Z1 palaeogeography in the NEGB, showing a large marginal A1 platform and widely deposited Na1 in the east of the basin (modified from $[58,62]$ ). 


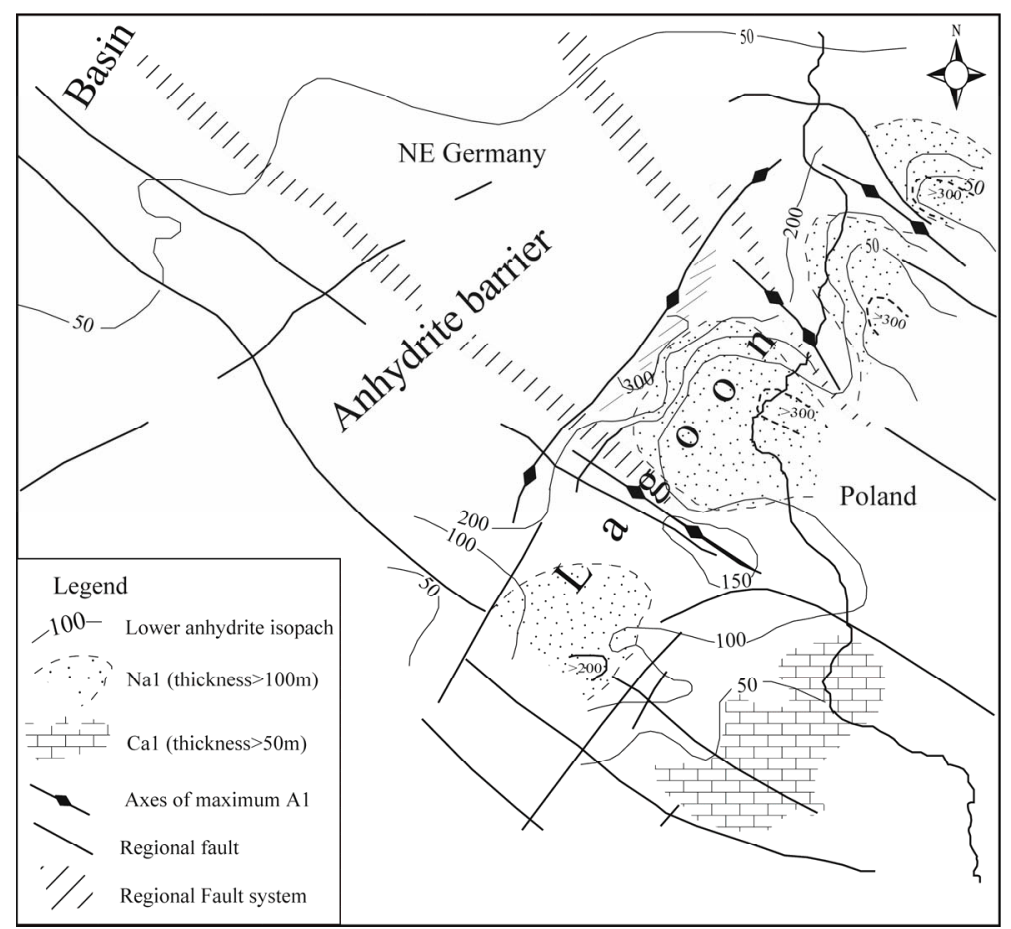

Figure 5. Facies and thickness of the $\mathrm{Z1}$ in the east of the NEGB. Very thick Na1 (50 to $>300 \mathrm{~m}$ ) deposited in the lagoon behind A1 barriers, whereas the thickness of Na1 decreased sharply towards the basin center, indicating intensive changes of depositional environments (probably related to paleo-topography, modified from [59]).

to basin the thickness of $\mathrm{Na} 1$ changes sharply, indicating an intensive variation of the salt depositional environments (Figure 5). Nal consists of predominant white halite (nearly over $90 \%$ ) and minor potash salts. Potash salts (K- or Mg-salts) are mostly intercalation with $2 \mathrm{~m}$ to $10 \mathrm{~m}$ thickness within a considerable amount of halite beds and they are restricted to the most continental edge where the evaporation rate was the highest. Potash salts are predominantly composed of sylvite $(\mathrm{KCl})$, carnallite $\left(\mathrm{KClMgCl}_{2} \cdot 6 \mathrm{H}_{2} \mathrm{O}\right)$ and kieserite $\left(\mathrm{MgSO}_{4} \cdot \mathrm{H}_{2} \mathrm{O}\right)$. The facies of these potash salts changed very quickly depending on their depositional environments, especially salinity of seawater. Where the potash salts deposited, the salinity of brine was the highest and these areas were probably isolated from the open sea at that time. Following a minor sea level rising, the accumulation of the $\mathrm{Na} 1$ was halted and another anhydrite $(\mathrm{A} 1 \beta$ and $\mathrm{A} 1 \alpha)$ were deposited with a high sedimentation rate in the NEGB.

In the surrounding areas of the NEGB, such as in Poland, the Oldest Halite (Na1) was deposited in saline pan to saline lagoon settings $[63,64]$. Because the Nal contain abundant primary textures and fabrics including chevrons, "hoppers", and cumulates of well-sorted fine crystals, it is used to infer the paleoenvironment of Zechstein salt via geochemical analyses (such as fluid inclusion, isotope analysis and $\mathrm{Br}$ concentration in the halite) and sedimentary facies [63-66]. For example, Peryt and Kovalevich [63] and Cendón et al. [65] suggested that fluid inclusions in halite of the Na1 have a similar ion composition with the evaporated modern seawater. The bromine $(\mathrm{Br})$ content in the $\mathrm{Na} 1$ indicates that the halite originated from evaporated Permian seawater.

\subsection{Zechstein 2 Salt (Na2)}

The second transgression started a new cycle of Zechstein deposits-Stassfurt (Z2) with the beginning of carbonate sedimentation. The Z2 transgression was slower than the $\mathrm{Z} 1$ transgression, which resulted in an extensive formation of carbonate platform $[16,18,19,58,60,61]$. The $\mathrm{Na} 2$ salt was widely distributed in the central part of the basin with a thickness from $200 \mathrm{~m}$ to over $600 \mathrm{~m}$ (Figure 6).

The Z2 salt deposition was multi-cyclic and which was probably triggered by minor transgressions as a result of salinity fluctuations. The lower Z2 salt grades from shallow-water halite into a deeper-water salt complex. The $\mathrm{Na} 2$ composes of major halite (about 95\%) with thin intercalations of anhydrite. At the base and top of the cycle, the $\mathrm{Na} 2$ contains potassium-magnesium salts including sylvite, carnallite and kieserite. In the NEGB, the facies of potash salts show a great variability, which indicates an unstable depositional environment [57]. The Z2 potash salt beds, especially at the top of $\mathrm{Na} 2$, are widely extended in the NEGB [58], which suggests that the climate is favorable for the precipitation of potash salt over the whole basin at the end of Z2. Based on the 
fluid inclusion data of the Z2 salt (e.g. sylvite), Vovnyuk and Czapowski [67] found that the chemical composition of primary inclusion in the halite belongs to the $\mathrm{Na}-\mathrm{K}-\mathrm{Mg}-\mathrm{Cl}-\mathrm{SO}_{4}\left(\mathrm{SO}_{4}\right.$-rich) type and they proposed that the $\mathrm{Z} 2$ salts were deposited at a higher temperature from concentrated seawater.

The thick Z2 salt sequence is the main regional top seal for the underlying gas/oil reservoirs. These thick salts have been suggested to involve in the extensive salt movements in the NEGB and they became the main diapiric salts in the whole Southern Permian Basin [28, 29,33,68]. Mesozoic and Cenozoic strata overlying the Z2 Salt have been strongly deformed, which complicates the reconstruction of the primary thickness and composition of Z2 salts $[8,10,11,48]$.

\subsection{Zechstein 3 Salt (Na3)}

Followed by the Platy Dolomite (Ca3) sedimentation, the $\mathrm{Na} 3$ salts were deposited almost the whole basin [62]. The Na3 was built up by a basal part of bedding halite and an upper part of thick potassium-magnesium salt layers. The thickness of the $\mathrm{Na} 3$ with predominated rock salt reaches $300 \mathrm{~m}$ to $400 \mathrm{~m}$ in the center of basin (Fig-

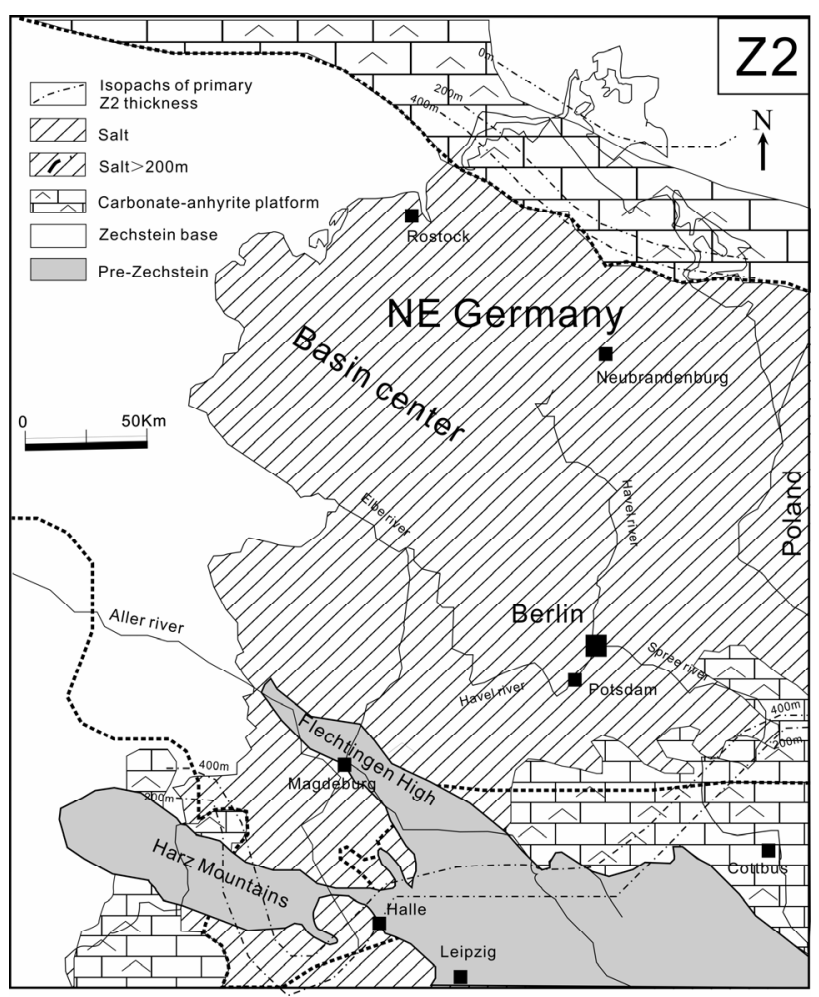

Figure 6. Z2 palaeogeography in the NEGB. The thick Na2 $(200$ to $>600 \mathrm{~m})$ in the basin center, reflects deeper water hypersaline environment and the major carbonate-anhydrite platform in the northern and southern margins, indicating shallow marine to saline conditions (based on [16, $58,62])$. ure 7). Their thickness changes gradually from platform to basin, suggesting that the heterogeneity of the PreZechstein basement was only slightly influenced by the lithofacies of Z3. The potash seams in Z3 are limited but well mineable over a wide area in the NEGB, which indicates that their deposits are controlled by the interaction of sea-level fluctuations and the paleorelief. These potash seams are rich in sylvinites and poor in Mg-salts [58].

\subsection{Zechstein 4 Salt (Na4) and Upper Zechstein Salt (Na5, Na6, Na7)}

The sedimentary conditions in the Zechstein basin started to change gradually at the end of the Z3 deposition due to the increasing isolation of the Zechstein basin and the moistening of climate. From the fourth transgression the Zechstein Sea in this basin became permanently hypersaline [19]. Red salt clays, as the base of Z4, were deposited in such a hypersaline condition. A considerable thick $\mathrm{Na} 4$ was precipitated in the whole basin (Figure 8). Its thickness is up to $150 \mathrm{~m}$ in the center of the basin $[56,62]$. In the lower part of $\mathrm{Na} 4$, massive rock salts and potassium-magnesium salts were supposed to deposit in a marine environment. In the upper part of $\mathrm{Na} 4$, the alternation of saliferous claystone and thin halite indicates a

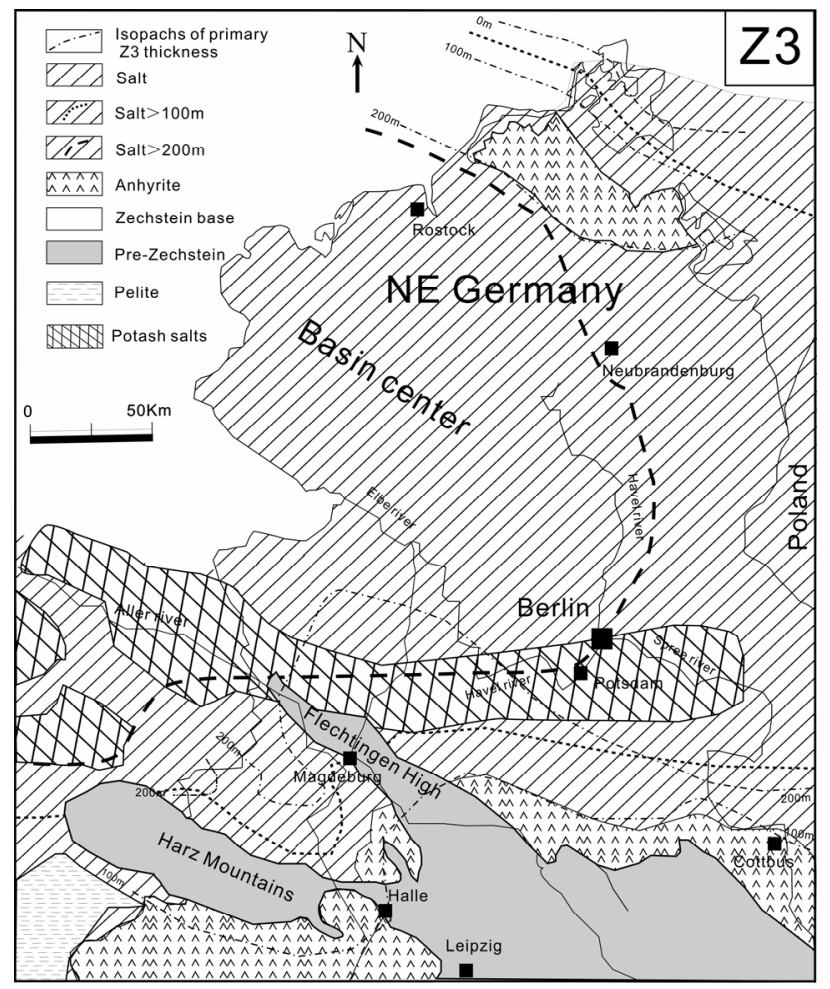

Figure 7. Z3 palaeogeography in the NEGB. Thick Na3 (300 - $400 \mathrm{~m}$ ) deposited nearly in the whole basin, indicating the evaporative environment extensively occurred at the end of Z3 (modified from [58,62]). 
gradual change on the playa environment. At the end of Z4 the connection with the Zechstein Sea was cut off and the basin was isolated from the open sea $[60,69]$.

Salts (Na5, Na6, Na7) sedimentation retreated increasingly towards the center of the basin [62]. The Na5 was deposited in the nearly whole NEGB, while Na6 mainly distributed in the northwest part of the basin. The youngest Zechstein salt, $\mathrm{Na7}$, is quite limited present northwest part of NEGB [62]. It is mainly distributed in Northwest German Basin [70]. At the end of Zechstein sedimentation, red continental sediments (Lower Triassic) entirely covered the whole basin.

\subsection{Comparison on the Zechstein Salts}

The Zechstein salts were deposited with a series of marine transgressions and regressions during the Upper Permian in the NEGB. Seven cycles of zechstein salts, $\mathrm{Na} 1, \mathrm{Na} 2, \mathrm{Na} 3, \mathrm{Na} 4, \mathrm{Na} 5, \mathrm{Na} 6$ and $\mathrm{Na}$, have been identified in this basin. The Nal was precipitated only in a trap area surrounding by the anhydrite barrier (Figures 4 and 5). The thickness of Nal is up to $300 \mathrm{~m}$ in the lagoon environment. It locally distributed in the east part of the NEGB. The Na2 is widely deposited in the whole basin (Figure 6). Its thickness is over $500 \mathrm{~m}$ in the center of the basin. The Na2 mainly consists of halite (about 95\%)

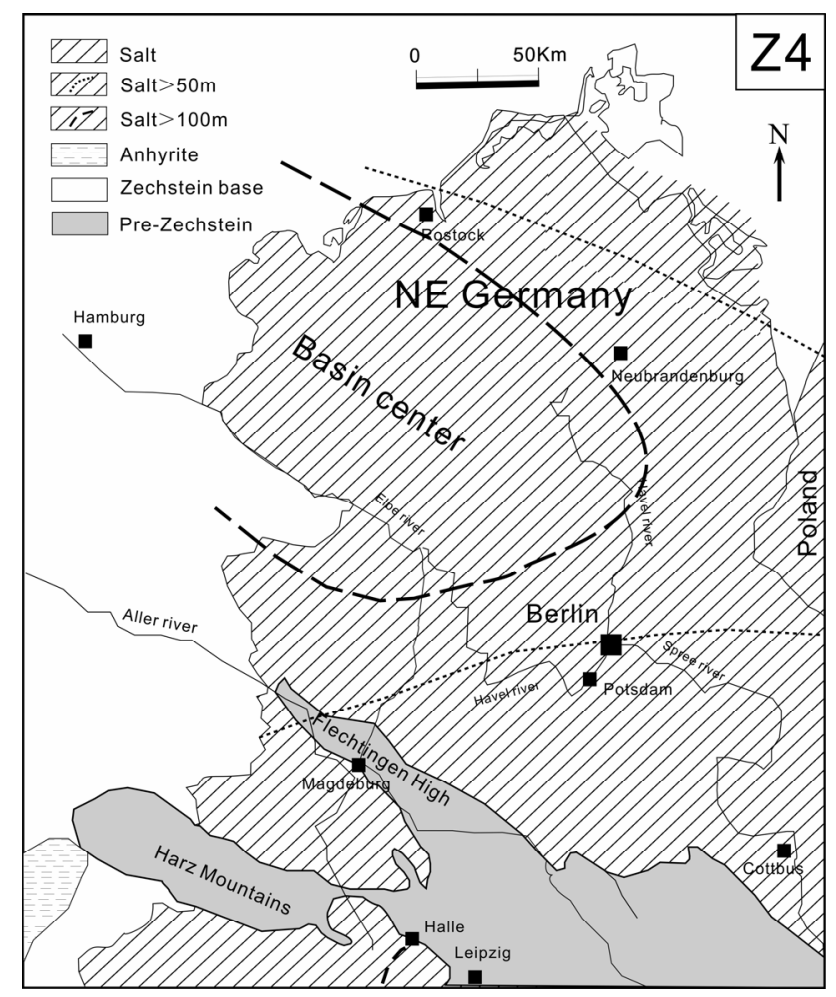

Figure 8. Z4 palaeogeography in the NEGB. Na4 deposited in the whole basin and the carbonate was absent, indicating that the Zechstein Sea was highly hypersaline during the formation of $\mathrm{Z4}$ (modified from [58,62]). with thin intercalations of anhydrite. Exception of its mineable value, the $\mathrm{Na} 2$ is the host rock for hydrocarbon source and the top seal for hydrocarbon reservoirs as well as the radioactive waste. The $\mathrm{Na} 3$ consists of a basal part of bedding halite and an upper part of thick potassiummagnesium salt layers. The thickness of $\mathrm{Na} 3$ reaches 300 $\mathrm{m}$ to $400 \mathrm{~m}$ in the center of the basin (Figure 7). Its thickness changes gradually from platform to basin. From the fourth transgression, the basin became permanently hypersaline. The thick Na4 were precipitated in the whole basin (Figure 8). Its thickness reaches $150 \mathrm{~m}$ in the center of the basin. The Na4 mainly consists of halite and potash salts. At the end of Z4, the connection with the Zechstein Sea was cut off and the basin was isolated from open sea. Salts ( $\mathrm{Na} 5, \mathrm{Na} 6$ and $\mathrm{Na} 7)$ sedimentation retreated increasingly towards the center of this basin [62]. The Na5 was deposited in the nearly whole NEGB, while the younger Zechstein salts. Na6 and $\mathrm{Na} 7$ mainly distributed in the northwest part of the basin.

\section{Evolution of Zechstein Salt}

\subsection{Salt Structures}

The density of salts (about $2200 \mathrm{~kg} / \mathrm{m}^{3}$ ) is lower than other surrounding sediments in the subsurface [57,61]. When the overburden is heavier than the salt, a positive buoyancy effect occurs [71]. Furthermore, the salts have a lower melting temperature and they become ductile at a temperature close to $245^{\circ} \mathrm{C}$ [72]. Therefore salt is in an unstable substance in the subsurface (under $500 \mathrm{~m}$ ). They behave as a visco-plastic flow in a geological timescale. Halokinesis (the process of flowing and rising of salt) occur when the differential pressure of stress exceeds the strength within the salts. In addition, due to the viscoplastic behaviour of salts, their layers usually act as a decoupling horizon between the substratums and the covers [57], resulting in the formation of different salt structures, such as salt pillows and salt diapirs.

Salt pillows termed by Trusheim [31], have the resultant sub-circular to elongated structures with a concordant overburden (Figure 9(a)). They are formed by a local thickening of the salt in terms of horizontal salt flow. Salt pillows have been investigated to discover the initiation of salt movement as well as the direction of salt movement [36,37]. Previous studies [33,39,73,74] suggested that the direction of salt flow changes from horizontal to vertical in the late pillow stage.

In the later evolution of salt pillows, they may reach the diapiric stage and form diapirs when salts pierce out their covers (Figure 9(b)). Thus a diapir has discordant contacts with overlying strata. Usually, salt diapirs are capped by young sediments. It was reported that the deformation (size, shape and type) of salt structures are highly dependent on many aspects, such as the composi- 

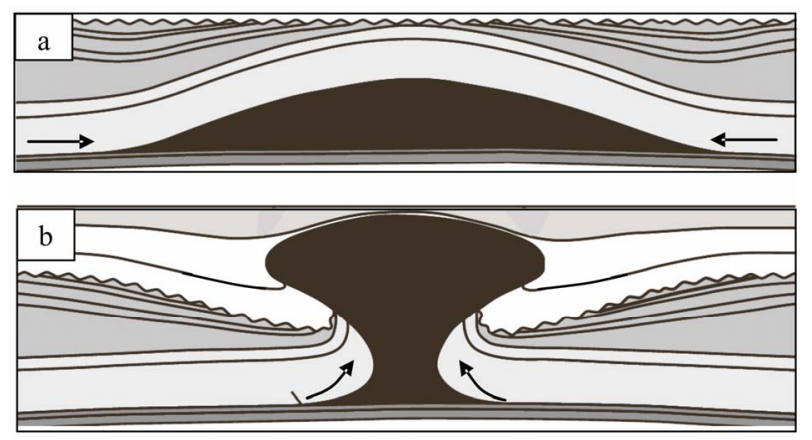

Legend: Salt $\rightleftharpoons$ Other sediments layers

Figure 9. Main types of salt structure. (a) Salt pillow, showing salt move in a lateral sense and the covers are not pierced by salt; (b) Salt diapir, showing that salts move in a vertical sense and salts pierce out the covers. Arrows show the direction of salt flow [43].

tion of salts, the position within the basin, the original thickness of the salts, the history of subsidence, sediment accumulation, the mechanical properties of sedimentary layers and the regional stress regime $[41,44,75,76]$. In most cases, the surrounding rocks determine the deformation of salt structures. While the salt composition also influence the deformation. For instance, a thin-bedded alternation of anhydrite and salt can be deformed in a ductile manner, while one thick layer of anhydrite embedded in salt deforms in a brittle way [73].

In the NEGB, a large number of salt pillows and salt diapirs developed as a result of extensive salt movements after Upper Permian deposition (Figure 10(a)). Salt pillows with low amplitude and long wavelength occur predominately in the northern and western part of the NEGB, whereas tall and narrow diapirs are the typical salt structure in the south-eastern region. The abundance and amplitude of salt structures increase at the Gardelegen Fault in the southern basin margin while they increase at the Rheinsberg Trough in the east, as well as at the Grimmen High in the northeastern margin $[8,10]$.

In the southern marginal part of the basin, salt diapirs with amplitude up to $4000 \mathrm{~m}$ are surrounded by salt withdrawal. Salt diapirs are aligned along axes parallel to the Gardelegen Fault and to the Rheinsberg Trough in the north of the Elbe Fault System. In contrast, salt deformation is less intensive in the northwestern part of the basin where only smooth, long wavelength salt pillows are developed. Salt layer with an average thickness of 1500 $\mathrm{m}$ in these pillows is presented. These salt pillows develop in various orientations, which are probably related to the direction of the stress field $[8,10]$. The pillow amplitudes, in the northern part of the NEGB, generally increase from about $100 \mathrm{~m}$ at the basin margin up to about $1800 \mathrm{~m}$ in the center of the basin [29]. In the northern and central areas of the basin the cores of the pillows are mainly composed of the Z2 (Stassfurt) salt.
The moving rate of the salt in a diapir is dependent on its thickness and available spaces [36,77]. The diapirism usually causes folds of salts in different orientations and microstructures, resulting in a complicated internal structure [78]. Regional compression during the Late Cretaceous to Early Cenozoic accelerates the rate of diapirism, and/or deforms some of the diapirs. So far, the complex internal structures in salt diapirs are still not very well known in the NEGB. Recently, the internal geometry of salt structures has been investigated for the exploration of hydrocarbon and other economic deposits within salt bodies [79-82]. Van Gent, Urai and De Keijzer [83] mapped the complex internal structure of Zechstein salt domes using 3D seismic reflection data in Netherlands. The seismic methods combined with numerical modeling gives a clear insight on the internal structure of salt bodies without extensive drilling and construction of galleries.

\subsection{Salt Movements}

The Zechstein salt, like other salts, behaves as a detachment layer between its overlying strata and its substrata. They are high mobile, which facilitate the buckling via flowing into the anticlines or piercing out its covers during the Post-Permian deformation in the NEGB. The movements of salts created distinct salt structures in the NEGB, which has attracted great attention $[35,41,42$, 84-86]. However, the trigger initiating the salt movement is hotly debated. On one hand halokinesis and halotectonics are regarded as the main trigger forces for the salt movement. The halokinesis includes buoyancy, differential loading, gravity spreading and thermal convective while the halotectonics contains compression, extension, flexural buckling of the overburden, salt reduction and drag. In 1960, after analyzing 200 salt structures, Trusheim [31] suggested the buoyancy (the density inversion) was the key factor for initiation of salt movement in the North German Basin. On the other hand, Kossow et al. [29] suggested that salt structures in the northern part of the NEGB could be a result of overburden buckling. Once salt movement is initiated, gravitational instability becomes an important factor due to its specific physical properties (low density, ductile deformation). Therefore buoyancy would play an important role in the deformation of the overlying of salt at a condition that the salts inflow laterally or vertically [35] Besides, with a heat-induced density inversion, thermal convection could lead to internal circulation, which further complicates the salt body, especially in the diapir.

In past decades, the regional tectonics is regarded as the major trigger for the movement of Zechstein salt in the NEGB because pulses of salt mobilization correlated temporally with the poly-phase regional tectonics in the 
NEGB (as show in Table 1) $[8,10,11,30,32,51]$. Based on the integrating results of 3D backstripping, 3D structural modeling and interpretation of seismic data, Scheck, Bayer and Lewerenz [8] and Hansen [32] suggested that salt movements in the NEGB mainly took place in two regional tectonics phases: Middle Triassic to Jurassic E-W directed extension interval and Late CretaceousEarly Cenozoic NNE-SSW directed compression interval. They proposed that salt started to move in a small scale at the Middle-Late Triassic, followed by an intensive movement during Jurassic extensional tectonics. The major phase of diapirs was formed in Late Cretaceous and Cenozoic time with basin-wide compression. In the central and southern parts of the NEGB, the salt structures were characterized by accelerated growth. Many of them pierced through their overlying strata at that time. However, Kossow et al. [28,29] did not agree with the initiation time of salt movement. Reason was the missing of obvious indicators of salt movement during Late Triassic in the northern part of the NEGB, although the E-W extension has been observed across the whole basin. Instead, Kossow proposed that salt movement was probably
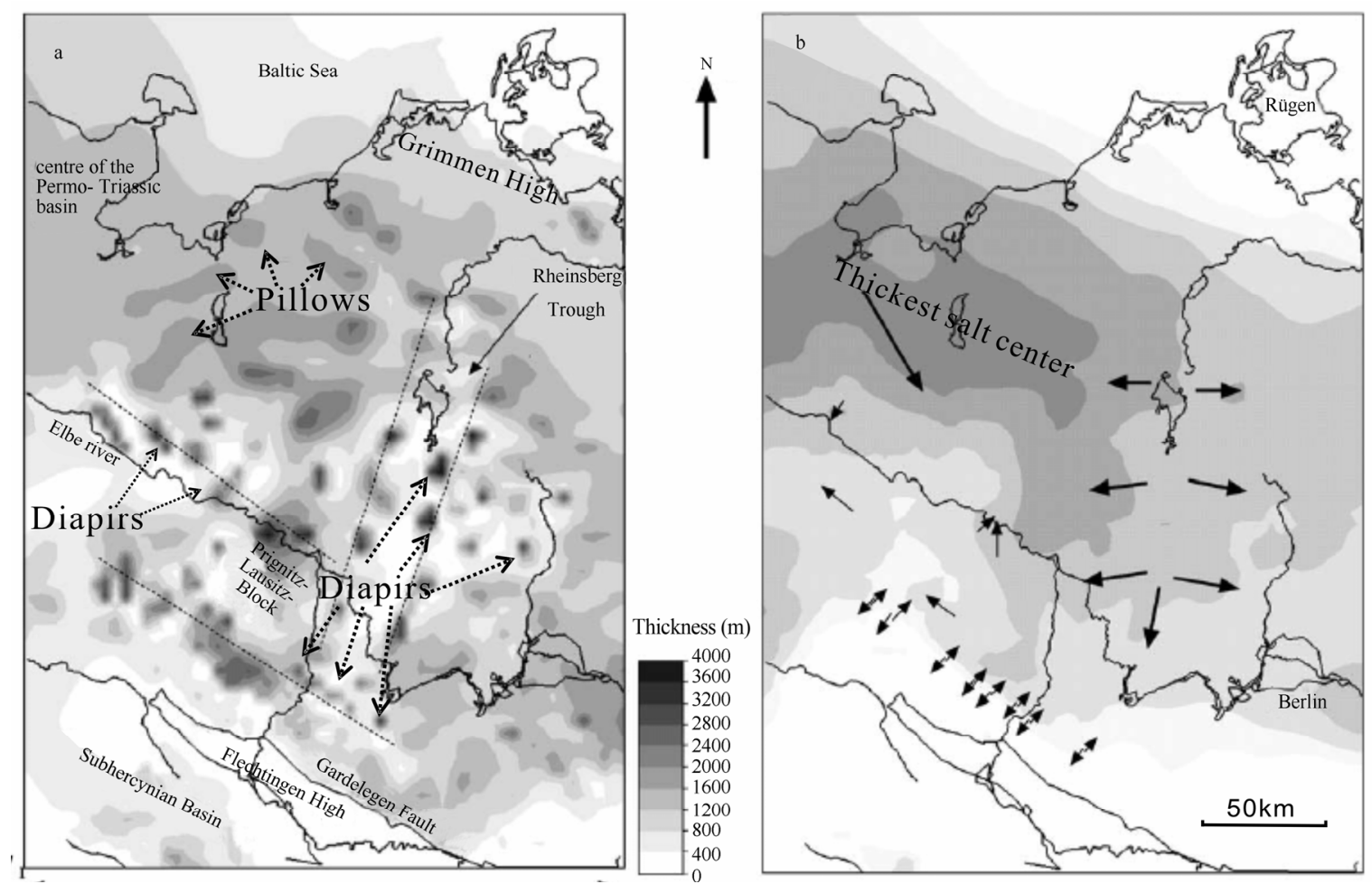

Figure 10. Distribution of Zechstein salt in the NEGB. (a) Present salt structure distribution shows salt pillows mainly in the NW part while most diapirs in the south-eastern area, indicating more intensive salt movements in southern areas; (b) Thickness of initial Zechstein salt indicates a NW-SE-oriented Zechstein basin and a depocentre in the northwest. Arrows show the main directions of salt movement: from the NW basin center to southern and eastern margins (modified from [8]).

Table 1. Tectonic regime and corresponding Zechstein salt movement in the NEGB (modified from [10,30]).

\begin{tabular}{|c|c|c|c|}
\hline \multirow{2}{*}{ Time Interval } & \multirow{2}{*}{ Tectonic Regime } & \multicolumn{2}{|c|}{ Salt Movement/Salt Structure } \\
\hline & & North Part of Basin & South Part of Basin \\
\hline Permian-Triassic & Thermal Subsidence & \multicolumn{2}{|c|}{ Stable Zechstein Salt } \\
\hline Middle Triassic-Jurassic & Thin-skinned E-W extension & Syn-sedimentary, minor salt lateral flow & $\begin{array}{l}\text { Syn-sedimentary, minor lateral flow } \\
\text { and uprise of salt; } \\
\text { Salt pillows and diapirs initiated }\end{array}$ \\
\hline $\begin{array}{c}\text { Late Cretaceous-Early } \\
\text { Tertiary }\end{array}$ & $\begin{array}{l}\text { Nearly NNE-SSW compression; } \\
\text { Partly basin inversion }\end{array}$ & $\begin{array}{l}\text { Strong salt flow; } \\
\text { Former pillow continued growth, } \\
\text { new pillows and several diapirs formed }\end{array}$ & $\begin{array}{l}\text { Much more strong salt uprise; } \\
\text { Many new diapirs developed }\end{array}$ \\
\hline
\end{tabular}


triggered by Late Jurassic to Early Cretaceous inversion tectonics in the northern part of the NEGB because most of salt pillows in this area were initiated in that time.

The primary thickness of salts has a substantial influence on salt movements and the deformation of its covers. Many advanced methods (such as back stripping, restoration section modeling and etc.) have been developed to disclose the initial salt thickness in this basin $[8,10$, $11,28,29]$. In the model of Kossow and Krawczyk [28], the maximal Zechstein salt thickness reaches $1850 \mathrm{~m}$ in the centre, $650 \mathrm{~m}$ at the south and $1050 \mathrm{~m}$ at the north of this basin. In the model of Scheck, Bayer and Lewerenz [8], the initial thickest of salt accumulates up to $2200 \mathrm{~m}$ in the Northwest of the basin (Figure 10(b)) which is in agreement with the result of Schwab [87], Kiersnowski et al. [88] and Strohmenger, Voigt and Zimdars [16]. From their models, the original Zechstein salt and overburden of salt are thickest in the northwestern part of the NEGB. However, in fact only limited salt pillows developed in this area. So Scheck, Bayer and Lewerenz [8] suggested that salt diapirism is difficult to form in this area because there is thick salt or thick overburden in the NEGB. However, this is not supported by the findings in the Northwest German Basin where salt diapirs largely developed in where the initial salt is thick whereas salt pillows form in where the initial salt is relatively thin $[89,90]$. This contradiction could be attributed to the different mechanism governing the movement of salts. If a fault is present in the overlying, their contribution on salt movements is more significant than the thickness of salts.

It is suggested that the salt migrated from the basin centre to the southern and eastern margins to fill the weakness zones during the salt movement (Figure 10(b)) [8]. But so far, there is limited knowledge about the exact timing or reasons of such a process. Scheck, Bayer and Lewerenz [8] reported that a possible reason could be the Jurassic-Early Cretaceous uplift of the northern part of the NEGB. This caused the development of a south-dipping slope at the Pre-Zechstein basement. This southdipping slope may have destabilized the isostatic equilibrium of the salt layer and initiated a down-slope salt flow without lateral displacement of the cover.

In the Southern Permian Basin, such as in the Netherland, the Northwest German Basin, and the Polish Basin, many Zechstein salt structures are related to large faults in the substrate [33,90-94]. However, no clear spatial relationship between the salt structures and basement faults was found in the northern and central parts of the NEGB [28] because the faults in these areas are too small to cut through the base of Zechstein.

\subsection{Salt Dissolution in the Subsurface}

When unsaturated water influxes/penetrates to salt deposits, the dissolution of salt deposites occurs due to the high solubility of salts. In the subsurface where the dissolution takes place, there are pathways for unsaturated water penetrating to salt deposits. The regional faulting or fracturing has been suggested to cause such a pathway initiating the salt dissolution [95]. The dissolution of rock salts in the subsurface can create pore space, differential stresses, creep and ultimately subsidence. In some cases, original rock salts can be leached to discontinuous remnants of varying thickness and areal extent.

In the NEGB, based on the seismic data interpretation, scientists suggested that salt loss is relative small amount due to salt dissolution in periods of salt movements. However, Kossow et al. [29] suggested that salt dissolution is a critical feature in the diapiric structures since significant quantities of salt may be dissolved when a salt pierce through the overlying strata and reaches the surface or comes in contact with aquifers. The Wesenberg diaper, for example, located in the north center of the basin, lost apprimately $54 \%$ of its original slat amout dut to dissolution. In such a case, the amount of salt loss due to dissolution might be considerable in the diapir or in the diapiric stage. Based on the structure restoration of the NEGB, Kossow and Krawczyk [28] suggested that the periods of increased salt loss coincide with the time of increased tectonic activity. During tectonically quiet phases, salt loss occurred mainly below the rim synclines. The Zechstein salt in the NEGB decreased discontinuously through time to a total loss of approximately $55 \%$. The loss rate increased during the Late Triassic when $\mathrm{E}-\mathrm{W}$ extension took place. This indicates that the majority of salt loss is probably caused by salt movements in the NEGB. However, the exact rate of salt loss due to salt dissolution is hotly debated.

Recently, salt dissolution has been intensively investigated because of groundwater salinization and exploration of thermal energy in the NEGB [52,96-99]. Many salt meadows and saline springs have been found in the NEGB as a result of salty water reaching the shallow aquifer system (Figure 11) [1,100]. It is found that highly salinity exists in deeper aquifer systems of the NEGB [101-104]. The infiltration of meteoric water dissolves salt bodies during the stage of diapirism. The existence of Permian evaporation brines have been suggested as a reason of the high salinity of the deep aquifer systems. Around $25 \%$ of the North Germany aquifer system is affected by inland salinity in terms of upcoming of deep-seated salt waters and dilution of salt diapirs (Figure 11) [98]. The major, rare-earth element and isotopes $(\mathrm{H}, \mathrm{O}, \mathrm{S}, \mathrm{Sr}, \mathrm{B})$ have been used to study the origin and processes of brines $[51,52,102,105,106]$. Tesmer et al. [52] suggested that the salinization of groundwater is mainly caused by halite $(\mathrm{NaCl})$ and halite $\mathrm{Ca}-\mathrm{Cl}$ brines in the NEGB. In this basin, hydrodynamic and hydrochemical behavior of brines are very variable within the 


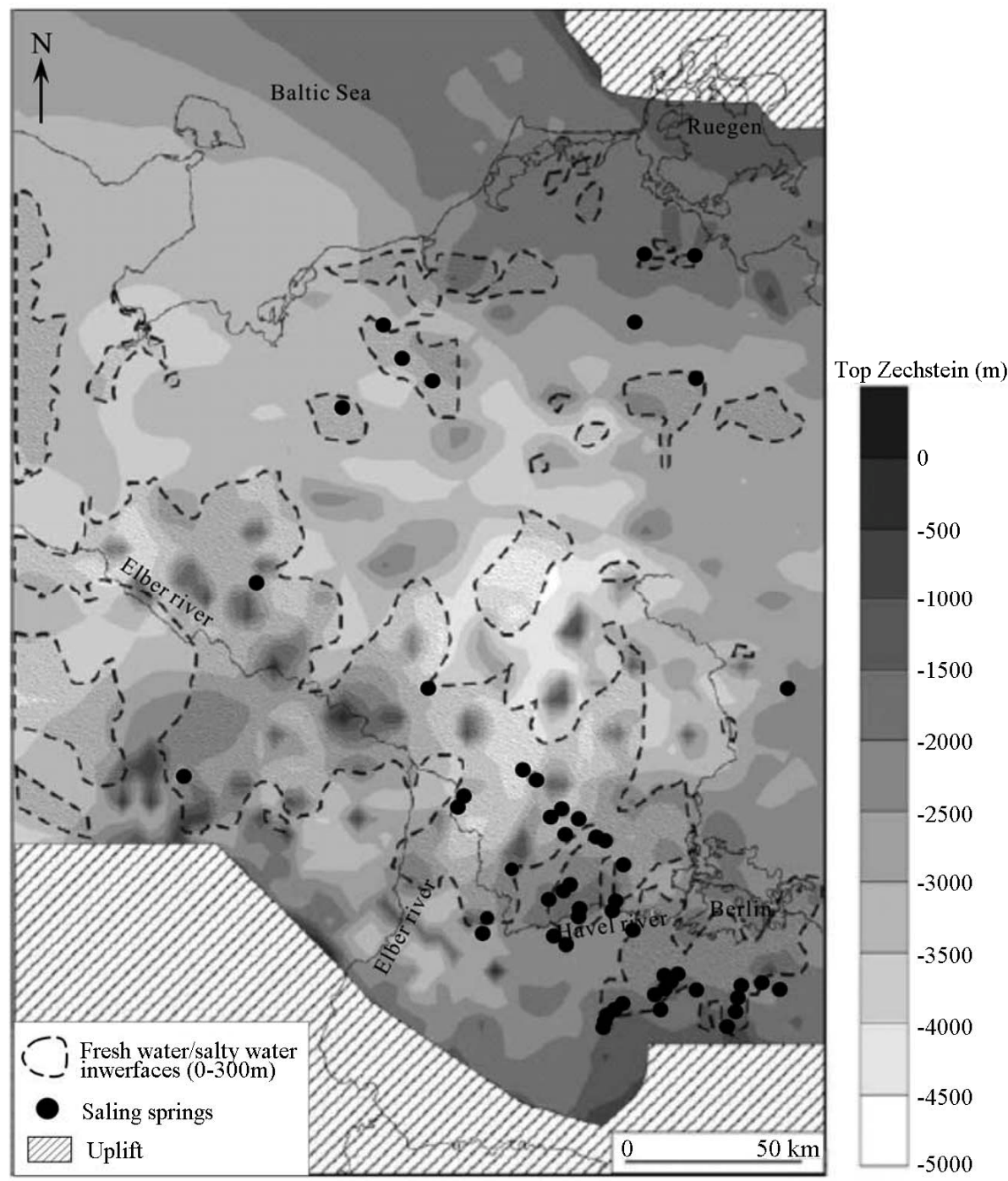

Figure 11. The distribution of the saline springs and salty groundwater interface in the top Zechstein salt of the NEGB, showing most saline springs in the south-eastern margin of the basin (neighbourhood of the Havel River and to the south of Berlin) (modified from $[97,107])$.

different aquifer complexes. An intensive salt diapirism leads to a complex geological environment with preferential flow paths and strong interactions among the temperature distribution, salt concentrations and groundwater flow fields. In addition, fluid-dynamics of driving saline water has been investigated to discover the groundwater salinization in the NEGB. Based on numerical simulations of transient thermohaline flow, Magri et al. [96] suggested that the upward flows of dissolved halite from deep- seated salt structures are driven by geothermal gradient in the NEGB.

\section{Summary and Prospect}

Seven cycles of Zechstein salts have been identified in this basin, from bottom to top, called Werra (Z1), Stassfur (Z2), Leine (Z3), Aller (Z4), Ohre (Z5), Friesland (Z6) and Fulda (Na7) salt. The composition, thickness and distribution of the salts are various, which are dependent on their depositional environments. The Na1 was only locally distributed in the marginal parts of the NEGB. $\mathrm{The} \mathrm{Na} 2$ was widely deposited in the whole basin with an enormous thickness (over $500 \mathrm{~m}$ ) in the center of the basin. The Na2 is an important reservoir rock for hydrocarbon storage caverns and radioactive waste disposal. The Na3 was precipitated in almost the whole basin. Its thickness increases gradually from the carbonate-anhydrite platform to the center of the basin, where the maximum thickness is $400 \mathrm{~m}$. The Na4 was widely precipitated in the whole basin with a smaller thickness (about $150 \mathrm{~m}$ in the basin centre) than the lower salts. The Na5 was distributed in the large part of the NEGB, while the $\mathrm{Na} 6$ and $\mathrm{Na} 7$ were only deposited in the center 
of the basin.

Salt movement has occurred after the regional tectonics in the NEGB, which changed the original distribution of the Zechstein salt and resulted in the formation of different salt structures such as pillows and diapirs. Pulses of salt movement correlate temporally with the polyphase regional tectonics in this basin. Salt movement was more intensive in southeastern part (especially along the southern margin) than the northwestern part of the basin. Salt pillows predominately developed in the northwest part of basin while the narrow and tall salt diapirs mainly formed in the southeastern marginal areas. The direction of salt flow was supposed from the basin center (NW part) to the southern and eastern margins. The process of salt flow created various types of structural traps for hydrocarbons in the NEGB. Fracturing and folding along the margins of salt diapirs provide both the traps for oil and gas and the escape route for upward migrating fluids.

The significance of salt movement has attracted great effort to disclosing the mechanism behind these movements. However, scientific contradiction and debate still remain. For example, even though the tectonics sounds reasonable to initiate the movement, it can not interpret the salt movement in the area without tectonic occurrence. Besides, in the northwest part of the basin, the thick salt was supposed to produce intensive diapirsum. But observed were just a few diapirs. The reason for such abnormal phenomenon is not clear so far. Furthermore, in some areas, salt movement was active while it was passive and even ceased in the neighboring places where the triggers for movements were present (e.g. basin margins). The reason for the locality of salt movements is not yet clarified in the NEGB. So, in the further investigation, these ambiguous questions and thermal dynamics related to salt should be considered, which probably bring us a better understanding of the processes of salt movement.

Many methods and technology have been used to study salt deposits and related structures. Except the sedimentology and stratigraphy approaches, the geochemistry (including major/trace elements, isotope elements ( $\mathrm{Sr}, \mathrm{S}, \mathrm{O}, \mathrm{H}, \mathrm{C}$ ), fluid/solid inclusion analysis) and geophysics (including seismic interpretation, 3D structure modeling, backstripping modeling and restoration section modeling) have been well developed. More recently, bromide $(\mathrm{Br})$ content in salts has been used to identify the processes or result of salt movement [108, 109]. Besides, X-ray texture goniometer has been used to analyze the microstructure of salt, which gives us a new view for the salt movement. In combination with the $\mathrm{Br}$ distribution, the microstructure of $\mathrm{Na} 2$ was supposed to date the real time of salt movement and to reveal the detailed processes of salt movement in a future study. With the advance of technologies, more and more new tools are expected to be used to clarify the uncertainty in NEGB as well as to predict the complex internal structures of salt bodies.

\section{Acknowledgements}

Y. Zhang thanks the student stipend from the University of Potsdam from 2008 to 2011.

\section{REFERENCES}

[1] M. Hannemann and W. Schirrmeister, "Paläohydrogeologische Grundlagen der Entwicklung der Süß-/Salzwassergrenze und der Salzwasseraustritte in Brandenburg [Paleo-Hydrogeological Principles of the Development of the Fresh-/Saltwater Interface and the Occurrence of Saline Springs in Brandenburg]," Bandenburgische Geowissenschaftliche Beiträge, Vol. 5, 1998, pp. 61-72.

[2] Y. I. Galushkin and G. Yakovlev, "Influence of Saline Deposits on the Conditions of Petroleum Generation in the Rocks Underlying the Salt Complex of the Northern Part of the Precaspian Basin," Geochemistry International, Vol. 45, No. 7, 2007, pp. 625-637. http://dx.doi.org/10.1134/S0016702907070014

[3] S. Grassmann, B. Cramer, G. Delisle, J. Messner and J. Winsemann, "Geological History and Petroleum System of the Mittelplate Oil Field, Northern Germany," International Journal of Earth Sciences, Vol. 94, No. 5-6, 2005, pp. 979-989.

http://dx.doi.org/10.1007/s00531-005-0018-x

[4] G. H. Isaksen, "Central North Sea Hydrocarbon Systems: Generation, Migration, Entrapment, and Thermal Degradation of Oil and Gas," AAPG Bulletin, Vol. 88, No. 11, 2004, pp. 1545-1572.

http://dx.doi.org/10.1306/06300403048

[5] L. Tang, Z. Jin, C. Jia, X. Pi and S. Chen, "Poly-Phase Salt Tectonics and Hydrocarbon Accumulation in Tarim Superimposed Basin, Northwest China," Science in China Series D: Earth Sciences, Vol. 47, Suppl. 2, 2004, pp. 104113. http://dx.doi.org/10.1360/04zd0029

[6] K. Glennie, "Recent Advances in Understanding the Southern North Sea Basin: A Summary," Geological Society, London, Special Publications, Vol. 123, No. 1, 1997, pp. 17-29. http://dx.doi.org/10.1144/GSL.SP.1997.123.01.03

[7] H. H. Posey and J. R. Kyle, "Fluid-Rock Interactions in the Salt Dome Environment: An Introduction and Review," Chemical Geology, Vol. 74, No. 1, 1988, pp. 1-24.

[8] M. Scheck, U. Bayer and B. Lewerenz, "Salt Movements in the Northeast German Basin and Its Relation to Major Post-Permian Tectonic Phases-Results from 3D Structural Modelling, Backstripping and Reflection Seismic Data," Tectonophysics, Vol. 361, No. 3, 2003, pp. 277 299. http://dx.doi.org/10.1016/S0040-1951(02)00650-9

[9] J.-D. Van Wees, R. Stephenson, P. Ziegler, U. Bayer, T. McCann, R. Dadlez, R. Gaupp, M. Narkiewicz, F. Bitzer and M. Scheck, "On the Origin of the Southern Permian Basin, Central Europe," Marine and Petroleum Geology, 
Vol. 17, No. 1, 2000, pp. 43-59.

http://dx.doi.org/10.1016/S0264-8172(99)00052-5

[10] M. Scheck, U. Bayer and B. Lewerenz, "Salt Redistribution during Extension and Inversion Inferred from 3D Backstripping," Tectonophysics, Vol. 373, No. 1, 2003, pp. $55-73$.

http://dx.doi.org/10.1016/S0040-1951(03)00283-X

[11] M. Scheck and U. Bayer, "Evolution of the Northeast German Basin-Inferences from a 3D Structural Model and Subsidence Analysis," Tectonophysics, Vol. 313, No. 1, 1999, pp. 145-169.

http://dx.doi.org/10.1016/S0040-1951(99)00194-8

[12] T. Peryt, "Basal Zechstein in Southwestern Poland: Sedimentation, Diagenesis, and Gas Accumulation," Sediment-Hosted Stratiform Copper Deposits: Geological Association of Canada Special Paper, Vol. 36, 1989, pp. 103-625.

[13] T. M. Peryt "Chronostratigraphical and Lithostratigraphical Correlations of the Zechstein Limestone in Central Europe," Geological Society, London, Special Publications, Vol. 22, No. 1, 1986, pp. 203-209. http://dx.doi.org/10.1144/GSL.SP.1986.022.01.19

[14] J. Paul, "Stratigraphy of the Lower Werra Cycle (Z1) in West Germany (Preliminary Results)," Geological Society, London, Special Publications, Vol. 22, No. 1, 1986, pp. $149-156$.

http://dx.doi.org/10.1144/GSL.SP.1986.022.01.13

[15] J. Paul, "Environmental Analysis of Basin and Schwellen Facies in the Lower Zechstein of Germany," Geological Society, London, Special Publications, Vol. 22, No. 1, 1986, pp. 143-147.

http://dx.doi.org/10.1144/GSL.SP.1986.022.01.12

[16] C. Strohmenger, E. Voigt and J. Zimdars, "Sequence Stratigraphy and Cyclic Development of Basal Zechstein Carbonate-Evaporite Deposits with Emphasis on Zechstein 2 Off-Platform Carbonates (Upper Permian, Northeast Germany)," Sedimentary Geology, Vol. 102, No. 1, 1996, pp. 33-54.

http://dx.doi.org/10.1016/0037-0738(95)00058-5

[17] C. Strohmenger and C. Strauss, "Sedimentology and Palynofacies of the Zechstein 2 Carbonate (Upper Permian, Northwest Germany): Implications for Sequence Stratigraphic Subdivision," Sedimentary Geology, Vol. 102, No. 1, 1996, pp. 55-77.

http://dx.doi.org/10.1016/0037-0738(95)00064-X

[18] D. B. Smith, "Rapid Marine Transgressions and Regressions of the Upper Permian Zechstein Sea," Journal of the Geological Society, Vol. 136, No. 2, 1979, pp. 155-156. http://dx.doi.org/10.1144/gsjgs.136.2.0155

[19] P. Ziegler, "Geological Atlas of Western and Central Europe: Shell Internationale Petroleum Maatschappij BV, Geological Society of London," Elsevier, Amsterdam, 1990.

[20] J. Taylor, "Upper Permian-Zechstein," K. W. Glennie, Ed., Blackwell, Oxford, 1998, pp. 174-211.

[21] R. Meinhold and H. Reinhardt, "Halokinese im Nordostdeutschen Tiefland," Berichte der Deutschen Gesellschaft für Geologische Wissenschaften, Vol. 12, No. 3-4, 1967, pp. 329-353.
[22] N. Rühberg, "Probleme der Zechsteinsalzbewegung," Zeitschrift für Angewandte Geologie, Vol. 22, No. 9, 1976, pp. 413-420.

[23] G. Richter-Bernburg, "Deformation within Salt Bodies," In: Dynamical Geology of Salt and Related Structures, Academic Press Inc., New York, 1987, pp. 39-75. http://dx.doi.org/10.1016/B978-0-12-444170-5.50007-5

[24] A. Goudie, "Salt Tectonics and Geomorphology," Progress in Physical Geography, Vol. 13, No. 4, 1989, pp. 597-605. http://dx.doi.org/10.1177/030913338901300405

[25] U. Bayer, M. Scheck and M. Koehler, "Modeling of the 3D Thermal Field in the Northeast German Basin," Geologische Rundschau, Vol. 86, No. 2, 1997, pp. 241-251. http://dx.doi.org/10.1007/s005310050137

[26] U. Bayer, M. Scheck, W. Rabbel, C. Krawczyk, H.-J. Götze, M. Stiller, T. Beilecke, A.-M. Marotta, L. BarrioAlvers and J. Kuder, "An Integrated Study of the NE German Basin," Tectonophysics, Vol. 314, No. 1, 1999, pp. 285-307.

http://dx.doi.org/10.1016/S0040-1951(99)00249-8

[27] M. Scheck, L. Barrio-Alvers, U. Bayer and H.-J. Götze, "Density Structure of the Northeast German Basin: 3D Modelling along the DEKORP Line BASIN96," Physics and Chemistry of the Earth, Part A: Solid Earth and Geodesy, Vol. 24, No. 3, 1999, pp. 221-230. http://dx.doi.org/10.1016/S1464-1895(99)00022-8

[28] D. Kossow and C. M. Krawczyk, "Structure and Quantification of Processes Controlling the Evolution of the Inverted NE-German Basin," Marine and Petroleum Geology, Vol. 19, No. 5, 2002, pp. 601-618. http://dx.doi.org/10.1016/S0264-8172(02)00032-6

[29] D. Kossow, C. Krawczyk, T. McCann, M. Strecker and J. F. Negendank, "Style and Evolution of Salt Pillows and Related Structures in the Northern Part of the Northeast German Basin," International Journal of Earth Sciences, Vol. 89, No. 3, 2000, pp. 652-664. http://dx.doi.org/10.1007/s005310000116

[30] M. B. Hansen, M. Scheck-Wenderoth, C. Hübscher, H. Lykke-Andersen, A. Dehghani, B. Hell and D. Gajewski, "Basin Evolution of the Northern Part of the Northeast German Basin-Insights from a 3D Structural Model," Tectonophysics, Vol. 437, No. 1, 2007, pp. 1-16. http://dx.doi.org/10.1016/j.tecto.2007.01.010

[31] F. Trusheim, "Mechanism of Salt Migration in Northern Germany," AAPG Bulletin, Vol. 44, No. 9, 1960, pp. 15191540 .

[32] M. B. Hansen, "Structure and Evolution of the Northern Part of the Northeast German Basin Revealed from Seismic Interpretation and 3D Structural Modelling," Ph.D. Thesis, University of Hamburg, Hamburg, 2005.

[33] M. C. Geluk, W. Paar and P. Fokker, "Salt," In: T. E. Wong, D. A. J. Batjes and J. De Jager, Eds., Geology of the Netherlands, Royal Netherlands Academy of Arts and Sciences (KNAW), Amsterdam, 2007, pp. 283-294.

[34] S. Stovba and R. Stephenson, "Style and Timing of Salt Tectonics in the Dniepr-Donets Basin (Ukraine): Implications for Triggering and Driving Mechanisms of Salt Movement in Sedimentary Basins," Marine and Petro- 
leum Geology, Vol. 19, No. 10, 2002, pp. 1169-1189. http://dx.doi.org/10.1016/S0264-8172(03)00023-0

[35] D. Waltham, "Why Does Salt Start to Move?" Tectonophysics, Vol. 282, No. 1, 1997, pp. 117-128. http://dx.doi.org/10.1016/S0040-1951(97)00215-1

[36] I. Davison, I. Alsop and D. Blundell, "Salt Tectonics: Some Aspects of Deformation Mechanics," Geological Society, London, Special Publications, Vol. 100, No. 1, 1996, pp. 1-10.

http://dx.doi.org/10.1144/GSL.SP.1996.100.01.01

[37] M. Hughes and I. Davison, "Geometry and Growth Kinematics of Salt Pillows in the Southern North Sea," Tectonophysics, Vol. 228, No. 3, 1993, pp. 239-254. http://dx.doi.org/10.1016/0040-1951(93)90343-I

[38] M. Jackson and B. Vendeville, "Regional Extension as a Geologic Trigger for Diapirism," Geological Society of America Bulletin, Vol. 106, No. 1, 1994, pp. 57-73. http://dx.doi.org/10.1130/0016-7606(1994)106<0057:RE AAGT $>2.3 . \mathrm{CO} ; 2$

[39] M. Jenyon, "Overburden Deformation Related to the PrePiercement Development of Salt Structures in the North Sea," Journal of the Geological Society, Vol. 145, No. 3, 1988, pp. 445-454. http://dx.doi.org/10.1144/gsigs.145.3.0445

[40] T. Nalpas and J.-P. Brun, "Salt Flow and Diapirism Related to Extension at Crustal Scale," Tectonophysics, Vol. 228, No. 3, 1993, pp. 349-362. http://dx.doi.org/10.1016/0040-1951(93)90348-N

[41] D. Schultz-Ela, M. T. Jackson and B. Vendeville, "Mechanics of Active Salt Diapirism," Tectonophysics, Vol. 228, No. 3, 1993, pp. 275-312. http://dx.doi.org/10.1016/0040-1951(93)90345-K

[42] S. A. Stewart and M. P. Coward, "Synthesis of Salt Tectonics in the Southern North Sea, UK," Marine and Petroleum Geology, Vol. 12, No. 5, 1995, pp. 457-475. http://dx.doi.org/10.1016/0264-8172(95)91502-G

[43] B. C. Vendeville, "A New Interpretation of Trusheim's Classic Model of Salt-Diapir Growth," Transactions-Gulf Coast Association of Geological Societies, Vol. 52, 2002, pp. 943-952.

[44] B. C. Vendeville and M. P. Jackson, "The Rise of Diapirs during Thin-Skinned Extension," Marine and Petroleum Geology, Vol. 9, No. 4, 1992, pp. 331-354.

http://dx.doi.org/10.1016/0264-8172(92)90047-I

[45] Dekorp-Basin Research Group, "Deep Crustal Structure of the Northeast German Basin: New DEKORP-BASIN'96 Deep-Profiling Results," Geology, Vol. 27, No. 1, 1999 , pp. 55-58. http://dx.doi.org/10.1130/0091-7613(1999)027<0055:DC $\mathrm{SOTN}>2.3 . \mathrm{CO} ; 2$

[46] R. Benek, W. Kramer, T. McCann, M. Scheck, J. Negendank, D. Korich, H.-D. Huebscher and U. Bayer, "PermoCarboniferous Magmatism of the Northeast German Basin," Tectonophysics, Vol. 266, No. 1, 1996, pp. 379-404. http://dx.doi.org/10.1016/S0040-1951(96)00199-0

[47] C. Breitkreuz and A. Kennedy, "Magmatic Flare-Up at the Carboniferous/Permian Boundary in the NE German Basin Revealed by SHRIMP Zircon Ages," Tectonophys- ics, Vol. 302, No. 3, 1999, pp. 307-326. http://dx.doi.org/10.1016/S0040-1951(98)00293-5

[48] M. Scheck, "3D Structural Modeling and Evolution of the Northeast German Basin," Terra Nova, Vol. 9, 1997, p. 185.

[49] H. Rieke, D. Kossow, T. McCann and C. Krawczyk, "Tectono-Sedimentary Evolution of the Northernmost Margin of the NE German Basin between Uppermost Carboniferous and Late Permian (Rotliegend)," Geological Journal, Vol. 36, No. 1, 2001, pp. 19-37. http://dx.doi.org/10.1002/gj.873

[50] A. Schmidt Mumm and M. Wolfgramm, "Diagenesis and fluid Mobilisation during the Evolution of the North German Basin-Evidence from Fluid Inclusion and Sulphur Isotope Analysis," Marine and Petroleum Geology, Vol. 19, No. 3, 2002, pp. 229-246. http://dx.doi.org/10.1016/S0264-8172(02)00015-6

[51] P. Möller, S. Weise, M. Tesmer, P. Dulski, A. Pekdeger, U. Bayer and F. Magri, "Salinization of Groundwater in the North German Basin: Results from Conjoint Investigation of Major, Trace Element and Multi-Isotope Distribution," International Journal of Earth Sciences, Vol. 97, No. 5, 2008, pp. 1057-1073. http://dx.doi.org/10.1007/s00531-007-0211-1

[52] M. Tesmer, P. Möller, S. Wieland, C. Jahnke, H. Voigt and A. Pekdeger, "Deep Reaching Fluid Flow in the North East German Basin: Origin and Processes of Groundwater Salinisation," Hydrogeology Journal, Vol. 15, No. 7, 2007, pp. 1291-1306. http://dx.doi.org/10.1007/s10040-007-0176-y

[53] H.-D. Vosteen, V. Rath, A. Schmidt-Mumm and C. Clauser, "The Thermal Regime of the Northeastern-German Basin from 2-D Inversion," Tectonophysics, Vol. 386, No. 1, 2004, pp. 81-95. http://dx.doi.org/10.1016/j.tecto.2004.05.004

[54] M. Menning, "A Numerical Time Scale for the Permian and Triassic Periods: An Integrated Time Analysis," In: The Permian of Northern Pangea: Paleogeography, Paleoclimates, Stratigraphy, Springer Berlin Heidelberg, Berlin, 1995, pp. 77-97. http://dx.doi.org/10.1007/978-3-642-78593-1 6

[55] H. Lippolt, S. Hautmann and J. Pilot, "40 Ar/39 Ar-Dating of Zechstein Potash Salts: New Constraints on the Numerical Age of the Latest Permian and the P-Tr Boundary," EUG (European Union of Geosciences) VII, Terra Abstract, Vol. 7, 1993, p. 591.

[56] K. Glennie, "Development of NW Europe's Southern Permian Gas Basin," Geological Society, London, Special Publications, Vol. 23, No. 1, 1986, pp. 3-22. http://dx.doi.org/10.1144/GSL.SP.1986.023.01.01

[57] J. Warren, "Evaporites: Their Evolution and Economics," Blackwell Science, Oxford, 1999.

[58] G. Richter-Bernburg, "Sedimentological Problems of Saline Deposits," Geology of Saline Deposits: Paris, UNESCO, Vol. 7, 1972, pp. 33-39.

[59] W. Rockel and W. Ziegenhardt, "Strukturelle Kriterien der Lagunenbildung im tieferen Zechstein im Raum südlich Berlin," Zeitschrift für Geologische Wissenschaften, Vol. 7, 1979, pp. 847-860. 
[60] J. Krzysztof, "An Overview of the Carboniferous and Permian in Poland," Proceedings of the XIII International Congress on the Carboniferous and Permian: Proceedings, Vol. 157, 1997, pp. 31-49.

[61] M. Geluk, "Permian Geology of the Netherlands," Royal Netherlands Academy of Arts and Sciences, Amsterdam, 2007, pp. 63-84.

[62] D. Franke, "Regionale Geologie von Ostdeutschland-Ein Wörterbuch," 2009.

[63] T. Peryt and V. Kovalevich, "Origin of Anhydrite Pseudomorphs after Gypsum Crystals in the Oldest Halite (Werra, Upper Permian, Northern Poland)," Zentralblatt für Geologie und Paläontologie, Vol. 1, 1996, pp. 337356.

[64] G. Czapowski, "Sedimentary Facies in the Oldest Rock Salt (Na1) of the Leba Elevation (Northern Poland)," Springer, Berlin, 1987, pp. 207-224.

[65] D. Cendón, J. Pueyo, C. Ayora, C. Taberner and T. Peryt, "Sulfate Starved Subbasins: Implications for Permian Seawater Composition," Geochimica et Cosmochimica Acta Supplement, Vol. 70, 2006, p. 91. http://dx.doi.org/10.1016/j.gca.2006.06.095

[66] G. Czapowski, "Facies characteristics and Distribution of the Zechstein [Upper Permian] Salt Deposits of PZ3 [Leine] Cycle in Poland," Bulletin of the Polish Academy of Sciences. Earth Sciences, Vol. 41, No. 4, 1993, pp. 229-237.

[67] S. Vovnyuk and G. Czapowski, "Generation of Primary Sylvite: The Fluid Inclusion Data from the Upper Permian (Zechstein) Evaporites, SW Poland," Geological Society, London, Special Publications, Vol. 285, No. 1, 2007, pp. 275-284. http://dx.doi.org/10.1144/SP285.16

[68] M. C. Geluk, "Stratigraphy and Tectonics of Permo-Triassic Basins in the Netherlands and Surrounding Areas," Ph.D. Thesis, Utrecht University, Utrecht, 2005.

[69] R. Wagner, "Stratigraphy and Evolution of the Zechstein Basin in the Polish Lowland," Państwowy Instytut Geologiczny, Warszawa, 1994, pp. 1-75.

[70] M. Hiete, U. Berner, C. Heunisch and H.-G. Rohling, "A High-Resolution Inorganic Geochemical Profile across the Zechstein-Buntsandstein Boundary in the North German Basin," Zeitschrift der Deutschen Gesellschaft für Geowissenschaften, Vol. 157, No. 1, 2006, pp. 77-105. http://dx.doi.org/10.1127/1860-1804/2006/0157-0077

[71] M. E. Tucker, "Sequence Stratigraphy of CarbonateEvaporite Basins: Models and Application to the Upper Permian (Zechstein) of Northeast England and Adjoining North Sea," Journal of the Geological Society, Vol. 148, No. 6, 1991, pp. 1019-1036. http://dx.doi.org/10.1144/gsigs.148.6.1019

[72] W. B. Heroy, "Thermicity of Salt as a Geologic Function," Geological Society of America Special Papers, Vol. 88, 1968, pp. 619-630.

[73] F. Lotze, "Steinsalz und Kalisalze; I Teil (AllgemeinGeologischer Teil)," Berlin-Nikolassee, Gebriider Borntraeger, 1957.

[74] M. K. Jenyon, "Salt Tectonics," Elsevier Applied Science Publishers, Barking, 1986.
[75] B. Vendeville and K. Nilsen, "Episodic Growth of Salt Diapirs Driven by Horizontal Shortening," In: C. J. Travis, H. Harrison, M. R. Hudec, B. C. Vendeville, F. J. Peel and B. F. Perkins, Eds., Salt, Sedimeng, and Hydrocarbons. Society of Economic and Paleontologists and Mineralogists, Gulf Coast Section, 16 ${ }^{\text {th }}$ Annual Research Foundation Conference, pp. 285-295.

[76] G. Einsele, "Sedimentary Basins: Evolution, Facies, and Sediment Budget," Springer Verlag, Berlin, 2000. http://dx.doi.org/10.1007/978-3-662-04029-4

[77] D. H. Kupfer, "Shear Zones inside Gulf Coast Salt Stocks Help to Delineate Spines of Movement," AAPG Bulletin, Vol. 60, No. 9, 1976, pp. 1434-1447.

[78] G. Richter-Bernburg, "Salt Tectonics, Interior Structures of Salt Bodies," Bulletin Centres Recherches Exploration-Production Elf Aquitaine, Vol. 4, 1980, pp. 373-389.

[79] H. A. Koyi, "Modeling the Influence of Sinking Anhydrite Blocks on Salt Diapirs Targeted for Hazardous Waste Disposal," Geology, Vol. 29, No. 5, 2001, pp. 387 390.

http://dx.doi.org/10.1130/0091-7613(2001)029<0387:MT IOSA $>2.0 . \mathrm{CO} ; 2$

[80] C. Talbot and P. Aftabi, "Geology and Models of Salt Extrusion at Qum Kuh, Central Iran," Journal of the Geological Society, Vol. 161, No. 2, 2004, pp. 321-334. http://dx.doi.org/10.1144/0016-764903-102

[81] L. Reuning, J. Schoenherr, A. Heimann, J. L. Urai, R. Littke, P. Kukla and Z. Rawahi, "Constraints on the Diagenesis, Stratigraphy and Internal Dynamics of the Surface-Piercing Salt Domes in the Ghaba Salt Basin (Oman): A Comparison to the Ara Formation in the South Oman Salt Basin," GeoArabia, Vol. 14, No. 3, 2009, pp. 83-120.

[82] J. Schoenherr, Z. Schléder, J. L. Urai, R. Littke and P. A. Kukla, "Deformation Mechanisms of Deeply Buried and Surface-Piercing Late Pre-Cambrian to Early Cambrian Ara Salt from interior Oman," International Journal of Earth Sciences, Vol. 99, No. 5, 2010, pp. 1007-1025. http://dx.doi.org/10.1007/s00531-009-0443-3

[83] H. Van Gent, J. L. Urai and M. De Keijzer, "The Internal Geometry of Salt Structures-A First Look Using 3D Seismic Data from the Zechstein of the Netherlands," Journal of Structural Geology, Vol. 33, No. 3, 2011, pp. 292-311. http://dx.doi.org/10.1016/j.jsg.2010.07.005

[84] C. Talbot, "Halokinesis and Thermal Convection," Nature, Vol. 273, 1978, pp. 739-741.

[85] H. Ramberg and H. Ramberg, "Gravity, Deformation and the Earth's Crust: In Theory, Experiments and Geological Application," Academic Press, London, 1981.

[86] M. Jackson and C. Talbot, "External Shapes, Strain Rates, and Dynamics of Salt Structures," Geological Society of America Bulletin, Vol. 97, No. 3, 1986, pp. 305-323. http://dx.doi.org/10.1130/0016-7606(1986)97<305:ESSR $\mathrm{AD}>2.0 . \mathrm{CO} ; 2$

[87] G. Schwab, "Paläomobilität der Norddeutsch-Polnischen Senke," Unpublished Thesis B, Akademie der Wissenschaften der DDR, Potsdam, 1985.

[88] H. Kiersnowski, J. Paul, T. M. Peryt and D. B. Smith, 
"Facies, Paleogeography, and Sedimentary History of the Southern Permian Basin in Europe," Springer, Berlin, 1995, pp. 119-136.

[89] Y. Maystrenko, U. Bayer and M. Scheck-Wenderoth, "The Glueckstadt Graben, a Sedimentary Record between the North and Baltic Sea in North Central Europe," Tectonophysics, Vol. 397, No. 1, 2005, pp. 113-126. http://dx.doi.org/10.1016/i.tecto.2004.10.004

[90] Y. Maystrenko, U. Bayer and M. Scheck-Wenderoth, "Structure and Evolution of the Glueckstadt Graben due to Salt Movements," International Journal of Earth Sciences, Vol. 94, No. 5-6, 2005, pp. 799-814. http://dx.doi.org/10.1007/s00531-005-0003-4

[91] J. Lamarche, M. Scheck and B. Lewerenz, "Heterogeneous Tectonic Inversion of the Mid-Polish Trough Related to Crustal Architecture, Sedimentary Patterns and Structural Inheritance," Tectonophysics, Vol. 373, No. 1, 2003, pp. 75-92. http://dx.doi.org/10.1016/S0040-1951(03)00285-3

[92] J. Lamarche and W. M. Scheck, "3D Structural Model of the Polish Basin," Tectonophysics, Vol. 397, No. 1, 2005, pp. 73-91.

[93] G. Remmelts, "Fault-Related Salt Tectonics in the Southern North Sea, the Netherlands," In: D. G. R. M. P. A. Jackson and S. Snelson, Eds., AAPG Memoir 65, 1995. pp. 261-272. http://dx.doi.org/10.1016/j.tecto.2004.10.013

[94] G. Remmelts, "Salt Tectonics in the Southern North Sea, the Netherlands," Springer, Berlin, 1996, pp. 143-158.

[95] N. Anderson and R. Brown, "Dissolution and Deformation of Rock Salt, Stetter Area, Southeastern Albert," Canadian Journal of Exploration Geophysics, Vol. 28, No. 2, 1992, pp. 128-136.

[96] F. Magri, U. Bayer, V. Clausnitzer, C. Jahnke, H.-J. Diersch, J. Fuhrmann, P. Möller, A. Pekdeger, M. Tesmer and H. Voigt, "Deep Reaching Fluid Flow Close to Convective Instability in the NE German Basin-Results from Water Chemistry and Numerical Modelling," Tectonophysics, Vol. 397, No. 1, 2005, pp. 5-20. http://dx.doi.org/10.1016/i.tecto.2004.10.006

[97] F. Magri, U. Bayer, C. Jahnke, V. Clausnitzer, H. Diersch, J. Fuhrman, P. Möller, A. Pekdeger, M. Tesmer and H. Voigt, "Fluid-Dynamics Driving Saline Water in the North East German Basin," International Journal of Earth Sciences, Vol. 94, No. 5-6, 2005, pp. 1056-1069. http://dx.doi.org/10.1007/s00531-005-0497-9

[98] F. Magri, U. Bayer, A. Pekdeger, R. Otto, C. Thomsen and U. Maiwald, "Salty Groundwater Flow in the Shallow and Deep Aquifer Systems of the Schleswig-Holstein Area (North German Basin)," Tectonophysics, Vol. 470, No. 1, 2009, pp. 183-194. http://dx.doi.org/10.1016/j.tecto.2008.04.019

[99] F. Magri, U. Bayer, M. Tesmer, P. Möller and A. Pekdeger, "Salinization Problems in the NEGB: Results from Thermohaline Simulations," International Journal of Earth Sciences, Vol. 97, No. 5, 2008, pp. 1075-1085. http://dx.doi.org/10.1007/s00531-007-0209-8

[100] A. T. Grube, "Geogene Grundwasserversalzung in den Poren-Grundwasserleitern Norddeutschlands und ihre Bedeutung für die Wasserwirtschaft [Geogenic Groundwater Salinisation of Porous Aquifer Systems and Its Impact on Water Management]," DVGW-Technologiezentrum Wasser $(T Z W)$, Karlsruhe, 2000.

[101] A. Grube and B. Lotz, "Geological and Numerical Modeling of Geogenic Salinization in the Area of the Lübeck Basin (North Germany)," 18th Salt Water Intrusion Meeting, Cartagena, 31 May-3 June 2004, pp. 183-195.

[102] W. Kloppmann, P. Négrel, J. Casanova, H. Klinge, K. Schelkes and C. Guerrot, "Halite Dissolution Derived Brines in the Vicinity of a Permian Salt Dome (N German Basin). Evidence from Boron, Strontium, Oxygen, and Hydrogen Isotopes," Geochimica et Cosmochimica Acta, Vol. 65, No. 22, 2001, pp. 4087-4101. http://dx.doi.org/10.1016/S0016-7037(01)00640-8

[103] A. Nishri, H. Herbert, N. Jockwer and W. Stichler, "The Geochemistry of Brines and Minerals from the Asse Salt Mine, Germany," Applied Geochemistry, Vol. 3, No. 3, 1988, pp. 317-332.

http://dx.doi.org/10.1016/0883-2927(88)90109-6

[104] E. Warren and P. Smalley, "Spatial Variations in North Sea Formation Water Composition," Water Rock Interaction, Proceedings of the 7th International Symposium on Water-Rock Interaction/WRI-7, Park City, 1992, pp. 11291132.

[105]Z. A. Berner, D. Stüben, M. A. Leosson and H. Klinge, "S- and O-Isotopic Character of Dissolved Sulphate in the Cover Rock Aquifers of a Zechstein Salt Dome," Applied Geochemistry, Vol. 17, No. 12, 2002, pp. 1515-1528. http://dx.doi.org/10.1016/S0883-2927(02)00046-X

[106] M. Tesmer, R. Otto, A. Pekdeger, P. Möller, U. Bayer, F. Magri, J. Fuhrmann, G. Enchery, C. Jahnke and H. J. Voigt, "Migration Paths and Hydrochemical Processes of Groundwater Salinization in Different Aquifer Systems of the North German Basin," Terra Nostra, Vol. 5, 2005, pp. $123-126$

[107] W. Schirrmeister, "Aus der Literatur überlieferte Angaben über Natürliche Salzwasseraustritte an der GrundWasseroberfläche/Geländeoberfläche in Bran-Denburg," Brandenburgische Geowissenschaftliche Beiträge, Vol. 3, 1996, pp. 94-96.

[108] Y. Küster, "Bromide Distribution Characteristics in Bedded and Domal Rock Salts of the Stassfurt Formation (Zechstein 2): Implications for the Influence of Salt Migration-Related Processes," Geophysical Research Abstracts, Vol. 9, 2007, Article ID: 03369.

[109] Y. Küster, M. Schramm, O. Bornemann and B. Leiss, "Bromide Distribution Characteristics of Different Zechstein 2 Rock Salt Sequences of the Southern Permian Basin: A Comparison between Bedded and Domal Salts," Sedimentology, Vol. 56, No. 5, 2009, pp. 1368-1391. http://dx.doi.org/10.1111/j.1365-3091.2008.01038.x 